\title{
重力場と遠心力場における動的模型実験の 相似則の比較
}

\author{
林 健太郎 ${ }^{1} \cdot$ 藤井 斉昭 ${ }^{2} \cdot$ 村松 $^{\text {伴博 }}{ }^{3} \cdot$ 北條 一男 $^{4}$ \\ 1正会員 五洋建設株式会社技術研究所課長代理（广329-27 杤木県那須郡西那須野町四区町1534-1） \\ ${ }^{2}$ 正会員 工博 中央大学理工学部土木工学科教授（テ112 東京都文京区春日1-13-29） \\ ${ }^{3}$ 正会員 五洋建設株式会社中国支店広島港工事事務所（７334 広島市南区宇品西3-4-27） \\ 4正会員 株式会社竹中土木（广277 千葉県柏市柏911-1）
}

\begin{abstract}
近年のメカトロニクス技術の進歩により，遠心模型実験装置に小型の振動台を取付け，遠心力場におい て振動実験を行うことが可能となった。これにより，非常に規模の小さい数十七ンチメートルの模型を用 いて，実物に換算すると数メートルの地盤の地震時挙動を容易に実験的に検証する事が可能となった。し かしながら，遠心力場における振動実験はようやく実験が可能になったばかりであり，信頼性に関しては 不明な点も多い1，2)。このため, 従来行われてきた大型振動台実験とスケールの異なる相似な模型振動実 験を行い，飽和砂地盤の液状化現象に着目して実験結果を比較検討することにより，遠心力場の振動実験 の信頼性に関して検討を行った。この結果, 模型地盤の液状化現象を中心とした動的な挙動は大型振動台 実験と比べ定性的にほほ同様な結果が得られた。
\end{abstract}

Key Words : liquefaction, model test,centrifuge, similitude,sand,permeability

\section{1.まえがき}

構造物の挙動が解析的な検討だけでは十分でない 場合，しばしば模型を使った実験が行われる。模型 を使用して, 実物の挙動を推測する場合, 模型の挙 動と実物の挙動を関連付けるために, 相似則が用い られる。地盤を含む構造物の模型実験では, 応力状 態によって地盤の力学特性が変化するために, 形状 は相似にしても模型の挙動は相似とはならず, 模型 のサイズによって異なる挙動を示す場合が多い.こ のため, これらの縮尺率と模型の挙動を関連づける ために $2 つ の$ 解決策が用いられる.

その一つは, 模型の縮尺に見合った重力を作用さ せることにより, 強制的に模型内の応力状態を実物 と同等にする遠心模型実験であり, もう一方は, 地 盤物性の応力依存特性を考慮した相似則を用いるこ とにより, 縮尺率と模型の挙動を関連づける手法で ある. 動的な実験に関しては, 前者の遠心模型実験 装置にも加振装置が取り付けられ，遠心力場におけ る動的実験が行われるようになり，後者は一般に大 型振動台実験などに適用されている.

これらの $2 つ の$ 相似則の比較に関しては, Koseki et.al $(1995)^{3)}$ が地中埋設構造物の液状化時の挙動に関
する比較実験を行っている．実験結果によると液状 化時の揚圧力による破壊メカニスムなどは定性的に 再現されたが，過剩間隙水圧の消散過程は遠心場の 模型の方が速くなったことが報告されている. 本研 究では地中構造物に比べ偏荷重の大きい盛土構造物 模型を用いて遠心力場と重力場の模型振動実験を行 い, 飽和砂地盤の液状化現象に着目して, これら 2 つの実験手法に関して比較検討を行っている.

\section{2. 相似則について}

遠心模型実験と重力場における模型実験とでは模 型内部に作用する物体力が異なるため, それぞれに 応じた相似則が適用される。ここでは，それぞれの 模型実験に使用される相似則について整理を行い, 若干の考察を加えた。今回の一連の実験で使用した 遠心力場と重力場における相似則を表 - 1 に示す.

\section{（1）遠心力場の振動実験に関する相似則}

重力場において幾何学的形状の相似な $\mathrm{n}$ 分の 1 の 模型実験を行う場合, 同じ地盤材料を用いれば図 1 に示すように模型地盤に発生する応力は実物の応 力の $1 / \mathrm{n}$ となる. 土の応力と歪みの関係は非線形 

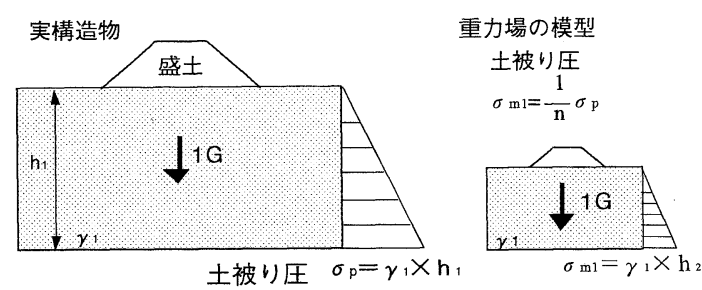

遠心場の模型

土被り圧

$\sigma \mathrm{m} 2=\sigma_{\mathrm{p}}$

$\gamma_{2}=\mathrm{n} \cdot \gamma_{1}$

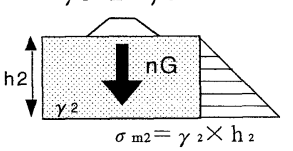

図-1 実物と模型の地盤内応力の比較

表ー 1 実験に使用した相似則一覧表

\begin{tabular}{|c|c|c|}
\hline 巣 位 & 重力場 & 遠心力場 \\
\hline 長 き & $1 / \mathrm{n}$ & $1 / \mathrm{n}$ \\
\hline 単位体積重量 & 1 & $1 / \mathrm{n}$ \\
\hline 時 間 & $1 / \mathrm{n}^{0.75}$ & $1 / \mathrm{n}$ \\
\hline 応 力 & $1 / \mathrm{n}$ & 1 \\
\hline 間隙水圧 & $1 / \mathrm{n}$ & 1 \\
\hline 変 位 & $1 / \mathrm{n}^{1.5}$ & $1 / \mathrm{n}$ \\
\hline 加速度 & 1 & $\mathrm{n}$ \\
\hline 地盤の透水係数 & $1 / \mathrm{n}^{0.75}$ & 1 \\
\hline
\end{tabular}

長さの縮尺比: $\mathrm{n}$

的であるため, 拘束圧が異なると応力と歪みの関係 は幾何学的な縮尺率と線形的な関係ではなくなる.

このため, 遠心模型実験では, 模型内部に幾何学的 な縮尺率 $(1 / \mathrm{n})$ に見合った $\mathrm{n}$ 倍の遠心加速度を 模型に作用することにより, 応力状態も含めて模型 地盤と実物とで相似な関係を満足させている4).

圧密現象などの間隙水の移動を取り扱う遠心模型 実験では, 長さの縮尺比を $1 / \mathrm{n}$ とすると, 透水条 件に関する連続の式から時間軸に関する相似則には $1 / \mathrm{n}^{2}$ が用いられる. しかしながら, 動的実験で は, 入力地震動を正弦波に置き換えて, 鉛直·水平 方向の加速度と変位の縮尺を一致させると時間軸の 縮尺率は 1 ／ $\mathrm{n}$ となるため, 上記の連続の式による ものと矛盾してしまう.

これらの矛盾をなくすために，遠心力場の実験で は模型地盤の透水係数の調整を行っている. 模型地 盤内の間隙水にグリセリン溶液などの粘性の高い材 料を使用することにより，模型地盤の透水係数を 1 / $\mathrm{n}$ に下げて, 時間軸に関する相似則は $1 / \mathrm{n}$ と し, 前述の振動特性式からの相似則との矛盾を無く している.

\section{（2）応力依存特性を考慮した重力場の相似則につ いて}

重力場における振動実験の相似則に関しては, い くつかの提案がなされている. 特に, 地盤の剛性の 応力依存特性を考慮した重力場における振動実験の 相似則は, 1978 年に香川 5゙よって提案されてい る.また, 国生らは飽和砂地盤の振動実験を行い, 地盤の振動応答の非線形性な変化に着目した相似則
を提案している6).

さらに, 水一地盤一構造物の連性系については, 現象を支配する一連の方程式を模型と実物とで満足 させることにより相似則を決定する手法を, 井合》 が提案している. 井合の相似則では, 水による飽和 地盤や矢板などの構造物などを含む系を対象として 拡張されており, 本研究では重力場における一連の 模型実験に対し，この相似則を使用した.

これらの一連の相似則では, 地盤の剛性 $(G)$ が

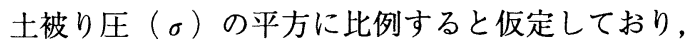
長さの縮尺比を $1 / \mathrm{n}$ とすると, 応力や水圧の縮尺 比は $1 / \mathrm{n}$, 歪みに関しては $1 / \mathrm{n}^{0.5}$, 時間軸に関 しては $1 / \mathrm{n}^{0.75}$ で与えられる.

模型の地盤や間隙水に実物と同じ材料を用いれ ば，遠心載荷の場合と同様に透水条件に関する連続 の式から時間軸に関する相似則は $1 / \mathrm{n}^{2}$ となる。こ のため, 井合の相似則では, 地盤の透水係数に関し て模型と実物との間に相似則を設けており, 模型地 盤の透水係数を $1 / \mathrm{n}^{0.75}$ に小さくする必要がある.

これらの条件より，圧密排水に関する時間係数 $\left(\mathrm{T}_{\mathrm{v}}\right)$ を算定する. せん断剛性率 $\mathrm{G}$ は, 土被り圧の 平方に比例するとしているため, $\mathrm{G}$ と逆比例関係に ある体積圧縮係数 $\mathrm{m}_{\mathrm{v}}$ は模型と実物とで以下のように 表される。

$$
\mathrm{m}_{\mathrm{vm}}=\mathrm{n}^{0.5} \times \mathrm{m}_{\mathrm{vp}}
$$

ここに $\mathrm{m}_{\mathrm{vm}}, \mathrm{m}_{\mathrm{vp}}$ : 模型と実物の体積圧縮係数

排水距離 $\mathrm{h}$, 透水係数 $\mathrm{k}$ おび体積圧縮係数 $\mathrm{m}_{\mathrm{v}}$ に上 記の関係を用いて時間係数 $\mathrm{T} 、$ を算定すると, 実物と 模型とでT、致することがわかる.

この透水係数に関する相似則は, 通常の振動実験 では加振時の挙動に与える影響が小さいとして無視 し, 模型でも実物と同じ透水係数の材料を用いる場 合が多い. しかしながら，この透水係数に関する相 似則に従えば，1／20程度の模型では地盤の透水 係数を実物の $1 / 10$ に下げなくてはならない. 今 回は, 透水係数に関する相似則を考慮して一連の実 験を行い, これらが加振時の挙動に与える影響につ いて検討を加えている. 
表一 2 実験ケース一覧表

\begin{tabular}{|c|c|c|c|c|c|}
\hline 実験名 & 想定構造物 & G-3 & $\overline{G-5}$ & G-10 & \begin{tabular}{|l|l|} 
C $-20-1$ & C -20-2 \\
\end{tabular} \\
\hline 縮尺率 & 1 & $1 / 3$ & $1 / 5$ & $1 / 10$ & $1 / 20$ \\
\hline 地盤深さ & $4.5 \mathrm{~m}$ & $1.5 \mathrm{~m}$ & $0.9 \mathrm{~m}$ & $0.45 \mathrm{~m}$ & $0.225 \mathrm{~m}$ \\
\hline 地盤幅 & $\overline{-}$ & $2.8 \mathrm{~m}$ & $1.8 \mathrm{~m}$ & $1.0 \mathrm{~m}$ & $0.60 \mathrm{~m}$ \\
\hline 地盤奥行 & - & $2.8 \mathrm{~m}$ & $1.8 \mathrm{~m}$ & $1.0 \mathrm{~m}$ & $0.25 \mathrm{~m}$ \\
\hline 実験場 & \multicolumn{4}{|c|}{ 重力場 } & 遠心力場 \\
\hline $\begin{array}{l}\text { 鉛直方向 } \\
\text { 加脨度 }\end{array}$ & \multicolumn{4}{|c|}{$1 \mathrm{G}$} & $20 \mathrm{G}$ \\
\hline 透水係数 & $1.21 \times 10^{-1}$ & $4.3 \times 10^{-2}$ & $4.3 \times 10^{-2}$ & $2.2 \times 10^{-2}$ & \begin{tabular}{c|c|c|c|c}
$\mathrm{cm} / \mathrm{s}$ & $5.6 \times 10^{-3} / \mathrm{s}$ \\
$\mathrm{cm}$
\end{tabular} \\
\hline
\end{tabular}

G-3：1／3模型地盤 重力場

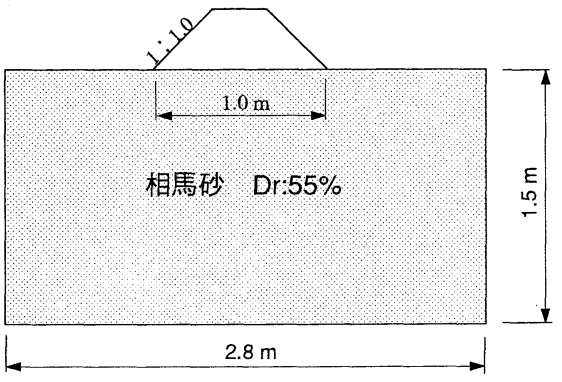

G-5：1／5模型地盤 重力場

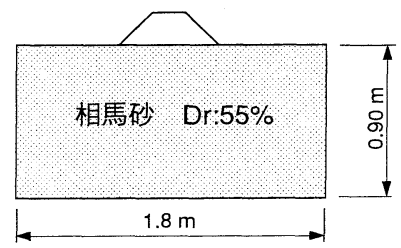

G-10：1／10 模型地盤 重力場

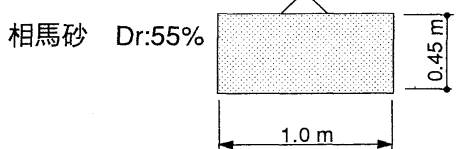

C- $20-1,2$ :

$1 / 20$ 模型地盤 遠心力場

相馬砂 Dr:55\%

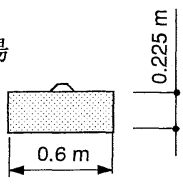

図一２模型実験のスケール比較図

\section{3. 実験内容}

上記遠心力場と重力場における二つの相似則を統 一的に検証するため, 一つの実地盤上の盛土構造物 を想定して，重力場と遠心力場において幾何学的に 相似な模型振動実験を行った。これら一連の実験で は縮尺が 1 ／3 から $1 / 20$ までの 4 つのサイズの
模型を使用して加振中, 加振後の地盤内応答加速 度, 間隙水圧分布, 盛土天端の沈下などを測定し た. 実験の結果はそれぞれの相似則に従い, 想定し た実物に換算して直接, 比較検討を行った。

盛土構造物の液状化に関する模型実験はこれまで にもいくつかあり, 古賀ら (1992) $)^{8)}$ は模型の縮尺や加 振波形を変えた遠心模型実験を行い, 地盤の挙動や 盛土の沈下特性について報告している，風間ら $(1996)^{9)}$ の研究では, 主に液状化後の残留変形量と円 弧すべりなどの関係について報告されている，本実 験は，これらの研究と実験手法的にはほぼ同じであ るが，重力場と遠心力場における液状化現象を中心 とした動的挙動の比較に着目している.

\section{（1）実験内容および検討ケース}

想定した土構造物は, 厚さ $4.5 \mathrm{~m}$ の砂地盤に載せら れた天端幅 $1.0 \mathrm{~m}$ 高さ $1.0 \mathrm{~m}$ の盛土構造物である.今 回の実験のケースは，表 - 2 に示すように，重力場 の実験では $1 / 3$ と $1 / 5 ， 1 / 10$ の三つのス ケールの比較的大きな模型振動実験を行った。ま た，遠心模型実験ではこれらの模型と幾何学的に相 似な $1 / 20$ のサイズの模型を作成し，20 Gの遠 心力場にて振動実験を行った。遠心模型実験では, 中央大学理工学部の遠心力載荷装置を使用した。本 載荷装置の有効半径は $3.05 \mathrm{~m}$ であり, 振動台の加振 方向は回転方向に対し接線方向である.

各実験で使用した模型を図－2に示す．同図より わかるように，地盤厚さは実物の $4.5 \mathrm{~m}$ に対し， G-3 では $1.5 \mathrm{~m}, \mathrm{G}-5$ では $0.9 \mathrm{~m}, \mathrm{G}-10 て ゙ は 0.45 \mathrm{~m}$, 遠心 力場のC-20-1および 2 では $0.225 \mathrm{~m}$ としている。 な お，地盤の水平長さに関しては土槽のサイズによる 制限もあるため, 水平長/深度の比で表すと最小が G-3で1.67〜最大がC-20で2.67程度のばらつきがあ る。実験土槽は，G-5 以外ではすべてせん断土槽を 使用している.

表 - 2 に示す重力場の G-3 およびG-5では, 飽和 地盤を作成するのに大量の間隙水を必要とすること 


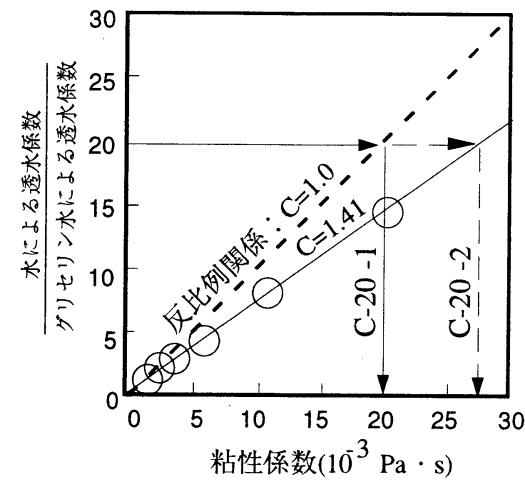

図一 3 間隙水の粘性と透水係数比の関係

から, 間隙水に水道水を使用し，その他の実験で は，粘性を調整したグリセリン水溶液を用いた。こ のため, 想定した実物地盤の透水係数は，G-3.およ びG - 5 の地盤に比べ $\mathrm{n}^{0.75}$ 倍程大きいものと仮定し て, 他ケースの見かけの透水係数を G-3,G-5の透水 係数と対比できるように粘性を調整した。

遠心模型実験では地盤の透水係数を調整するため に，シリコンオイルなどの粘度の高い材料が使用さ れる(10)が, 本実験では同様な性状を持つグリセリン 水溶液を使用した。

地盤中の間隙水の流れがダルシー則に従うとする と, 地盤の透水倸数は以下の式で表される.

$$
\begin{aligned}
\mathrm{k}=\mathrm{C} \cdot \frac{\mathrm{n} \cdot \gamma_{\mathrm{W}} \cdot \mathrm{a}^{2}}{8 \cdot \eta} \\
\mathrm{n} \quad: \text { 地盤の空隙率 } \\
\gamma_{\mathrm{w}}: \text { 水の単位体積重量 } \\
\mathrm{a}: \text { 空隙の平均半径 } \\
\eta \quad: \text { 水の粘性係数 } \\
\mathrm{C}: \text { 比例定数 }
\end{aligned}
$$

Sakemi et.al ${ }^{11), 12)}$ は10G 50Gの遠心力場で透水実験 を行い, 遠心力場で上記のダルシー則が成立するこ とを報告している。一方, 遠心模型実験と重力場の 実験を比較したKoseki et.al ${ }^{3)}$ は, ダルシー則に従っ て地盤の粘性を調整すると遠心場の過剩間隙水圧の 消散が重力場に比べて速くなることを報告してい る. 著者らは間隙水の粘性と透水係数の関係を求め るために模型地盤と同じ $\mathrm{Dr}=55 \%$ の相馬砂とグリセ リン水溶液を使用して定水位透水試験を行った．間 隙水の粘性と, 間隙水に水, グリセリン水溶液を使 用した場合の透水係数の比との関係を図 - 3 に示 す.この結果, 間隙水の粘性係数と地盤の透水係数 の間には完全な反比例の関係 $(\mathrm{C}=1.0)$ は認められない が, 上式の比例定数を $\mathrm{C}=1.41$ と経験的に設定するこ

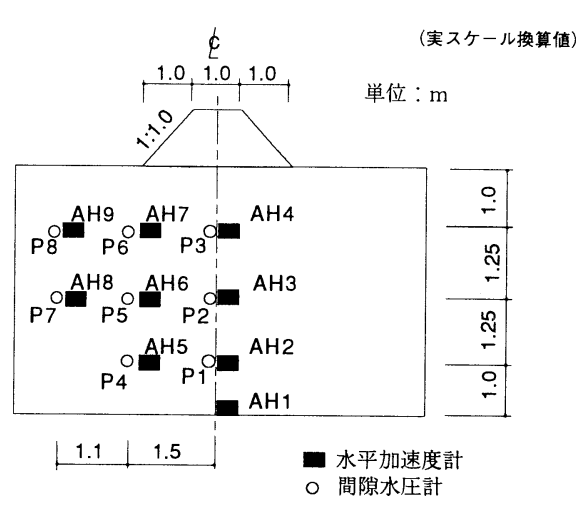

図-4 計器設置位置図

表一 3 相馬砂の物理特性

\begin{tabular}{|c|c|}
\hline 土粒子密度 $\rho_{\mathrm{s}}\left(\mathrm{gf} / \mathrm{cm}^{3}\right)$ & 2.61 \\
\hline 最大間隙比 $\mathrm{e}_{\max }$ & 1.096 \\
\hline 最小間隙比 $\mathrm{e}$ min & 0.653 \\
\hline 相 対密 度 $\mathrm{D}_{\mathrm{r}}(\%)$ & 55 \\
\hline 間 隙 比 $\mathrm{e}$ & 0.852 \\
\hline 単位体積重量 $\gamma \mathrm{d}\left(\mathrm{gf} / \mathrm{cm}^{3}\right)$ & 1.409 \\
\hline 透水係数 $\mathrm{k}(\mathrm{cm} / \mathrm{s})$ & $4.3 \times 10^{-2}$ \\
\hline 均 等 係 数 $\mathrm{U}_{\mathrm{c}}$ & 1.454 \\
\hline
\end{tabular}

とにより透水試験結果がうまく説明できる．今回の 実験では, 図 - 3 の関係を用いて模型の間隙水の粘 性を調整した。

相似則から $20 \mathrm{G}$ 遠心力場では，水を用いた場合 の $1 / 20$ の透水係数にすることが必要であるため, 同図から約 $27 \times 10^{-3} \mathrm{~Pa} \cdot \mathrm{s}$ の粘性の溶液が必要である ことがわかる.よって, G-3, G-5の重力場実験の相 似則と合わせると, $27 \times 10^{-3} \mathrm{~Pa} \cdot \mathrm{s} \times\left(1 / 5^{0.75} \sim 1 /\right.$ $\left.3^{0.75}\right)=8.25 \sim 12.09 \times 10^{-3} \mathrm{~Pa} \cdot \mathrm{s}$ の粘性が必要である. C-20-2では, 平均をとって $10 \times 10^{-3} \mathrm{~Pa} \cdot \mathrm{s}$ のグリセリ ン水溶液を使用した。比較のためにC-20-1では, 従 来の反比例の関係から粘性を決定し, $20 \times 10^{-3} \mathrm{~Pa} \cdot \mathrm{s}$ $\times\left(1 / 5^{0.75} \sim 1 / 3^{0.75}\right)=6.7 \times 10^{-3} \mathrm{~Pa} \cdot \mathrm{s}$ のグリセリン水 溶液を使用した。また, 重力場の実験であるG-10に ついても, 図 - 3 の関係から地盤の間隙水に $2.0 \times$ $10^{-3} \mathrm{~Pa} \cdot \mathrm{s}$ のグリセリン水を使用した.

\section{（2）模型地盤の作成方法}

模型地盤は水中落下法により相対密度 $\mathrm{Dr}=55 \%$ の 飽和砂地盤を作製し, 地盤の上に乾燥砂による盛土 構造物を設置して作製した. 重力場の模型は, 落下 高さと地盤密度の関係を予め実験より求め, 落下高 さ $90 \mathrm{~cm}$, 水位 $15 \mathrm{~cm}$ を保ちながら, 砂を均一に落下 させて飽和地盤を作製した，遠心力場における模型 は, 間隙水に粘度の高いグリセリン水溶液を使用す 
表-4 入力波形条件一覧表

\begin{tabular}{|c|c|c|c|c|c|c|}
\hline 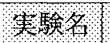 & 車構造聯 & 6.3 & G.5 & 6.10 & C 201 & $(-202$ \\
\hline 縮尺率 & 1 & $1 / 3$ & $1 / 5$ & $1 / 10$ & \multicolumn{2}{|c|}{$1 / 20$} \\
\hline 振動波形 & \multicolumn{6}{|c|}{ 正弦波, 60波 } \\
\hline 周波数 & $5 \mathrm{~Hz}$ & $11 \mathrm{~Hz}$ & $16.7 \mathrm{~Hz}$ & $28.1 \mathrm{~Hz}$ & \multicolumn{2}{|c|}{$100 \mathrm{~Hz}$} \\
\hline 最大加速度 & $\begin{array}{l}\text { 目菓值 } \\
147 \mathrm{gal}\end{array}$ & $\begin{array}{l}\text { 实测售 } \\
170 \mathrm{gal}\end{array}$ & $\begin{array}{l}\text { 実測値 } \\
215 \mathrm{gal}\end{array}$ & 実測值 & 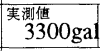 & 実测值 \\
\hline 継続時間 & $12 \mathrm{~s}$ & $5.45 \mathrm{~s}$ & $3.59 \mathrm{~s}$ & $2.13 \mathrm{~s}$ & 0.6 & \\
\hline
\end{tabular}

るため, $80^{\circ} \mathrm{C}$ 以上に温度を高めることによりグリセ リン水溶液の粘度を下げ，液面の高さを $2 \mathrm{~cm}$ と一定 にして水中落下法により飽和地盤を作製した。

盛土部分についても地盤部と同様に相対密度 $\mathrm{Dr}=$ $55 \%$ 相馬砂を用いて作成した．今回の実験では盛 土部分には木製の枠を用いているめ，風間らの盛土 の振動実験で見られたような盛土部分の崩壊は生じ ず，上載荷重としてだけ機能している。なお，盛土 の作成時にはサクションにより, 若干の地盤内の水 の吸い上げが生じた．飽和砂地盤の水位は加振前に 地盤面とほぼ一致するように調整した。

実験時の計測項目は地盤内部の間隙水圧, 加速 度, 及び盛土天端の沈下量の時刻歴および加振前後 の地表面の変位量である．実地盤に換算した各種計 測装置の設置位置を図 - 4 に示す.今回, 実験で使 用した砂は福島県相馬郡産の相馬砂である．相馬砂 の物理特性を表- 3 に示す.

\section{（3）入力波形}

実験で使用した波形は，入力波の時間軸は前章の 相似則に従い, 模型の縮尺率と実験の条件によって 変更した. 表 - 4 に各実験の入力波形条件を示す. 入力波は仮想した実構造物に対し, 最大加速度 $147 \mathrm{gal}$ の正弦波60波とした。

\section{（4）実験結果}

図 - 5 に各実験の土槽底板の入力加速度を示す. なお, これらの時刻歴図の時間軸は, 各相似則を用 いて実物の時間軸に，加速度も実物のものにそれぞ れ換算している.土槽底板の入力加速度をみると， すべてのケースで設定した加速度より $10 \%$ 程度大き い值となった．特に G- 5 では入力加速度の最大值 が210gal程度と大きくなっている．波形自体はすべ てのケースでほほ均一な正弦波であった。これよ り, 設定した条件に近い入力波が模型に作用してい ることがわかる。

図- 6 にG-3，G-5，G-10，C-20- 1 の盛土法尻 位置での深度毎の応答加速度の時刻歴を示す．剛な 土槽を使用した G-5では, 入力加速度に比べ地盤内
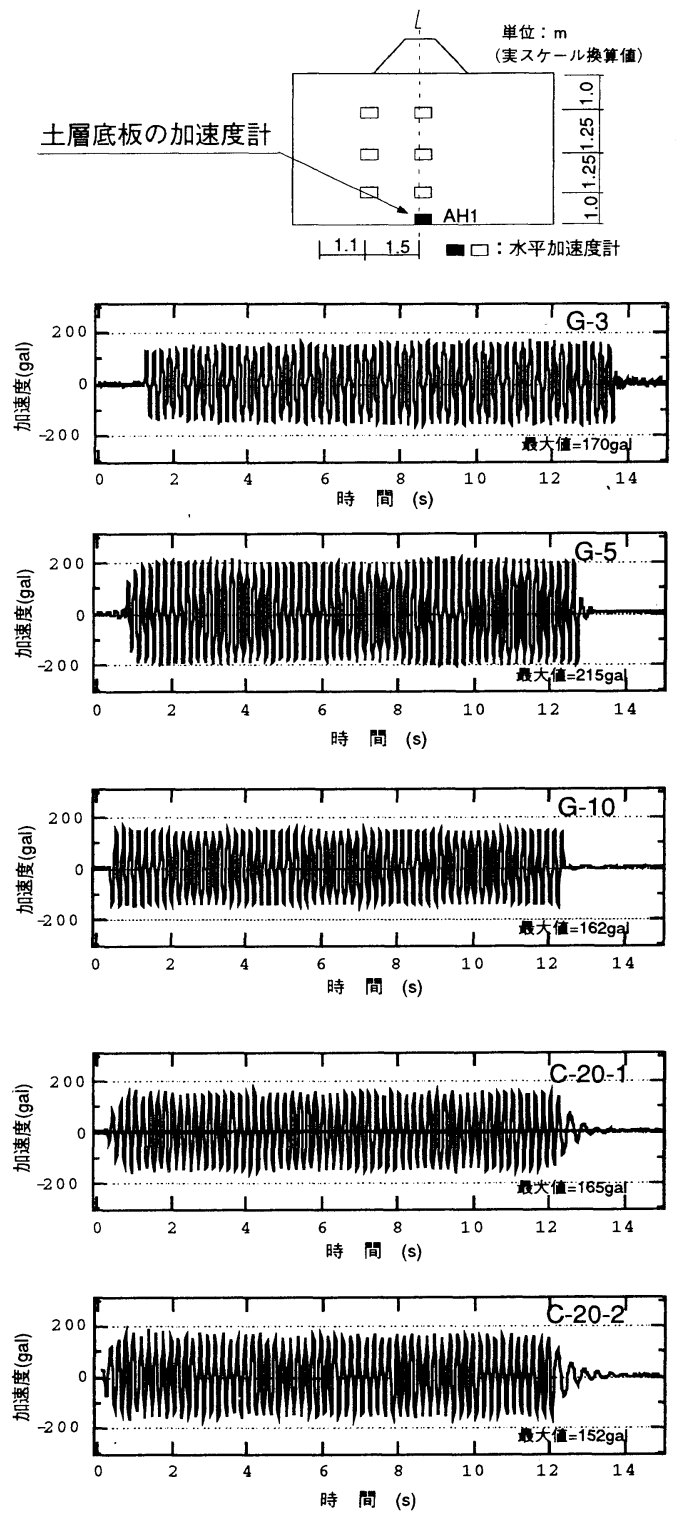

図 - 5 土槽底板の入力加速度時刻歴

部の応答加速度の方が大きくなっている。しかしな がら，せん断土槽を使用した他の実験では，入力加 速度に比べ地表面に近くなるにつれ応答加速度の最 大值は小さくなっている.

各実験の応答波形は定量的にはかなりばらついた 結果となったが, 定性的には次のような傾向のある ことがうかがえた。すなわち, 法尻の直下の地表面 に近いAH7では, 加振直後に応答加速度が減衰して 扔り，地盤剛性が低下している。一方，深い位置の A H 5 では, 各実験のパターンに多少の相違はある が, いずれも応答加速度の減衰は他の位置に比べ小 さく，初期の剛性を維持している. 

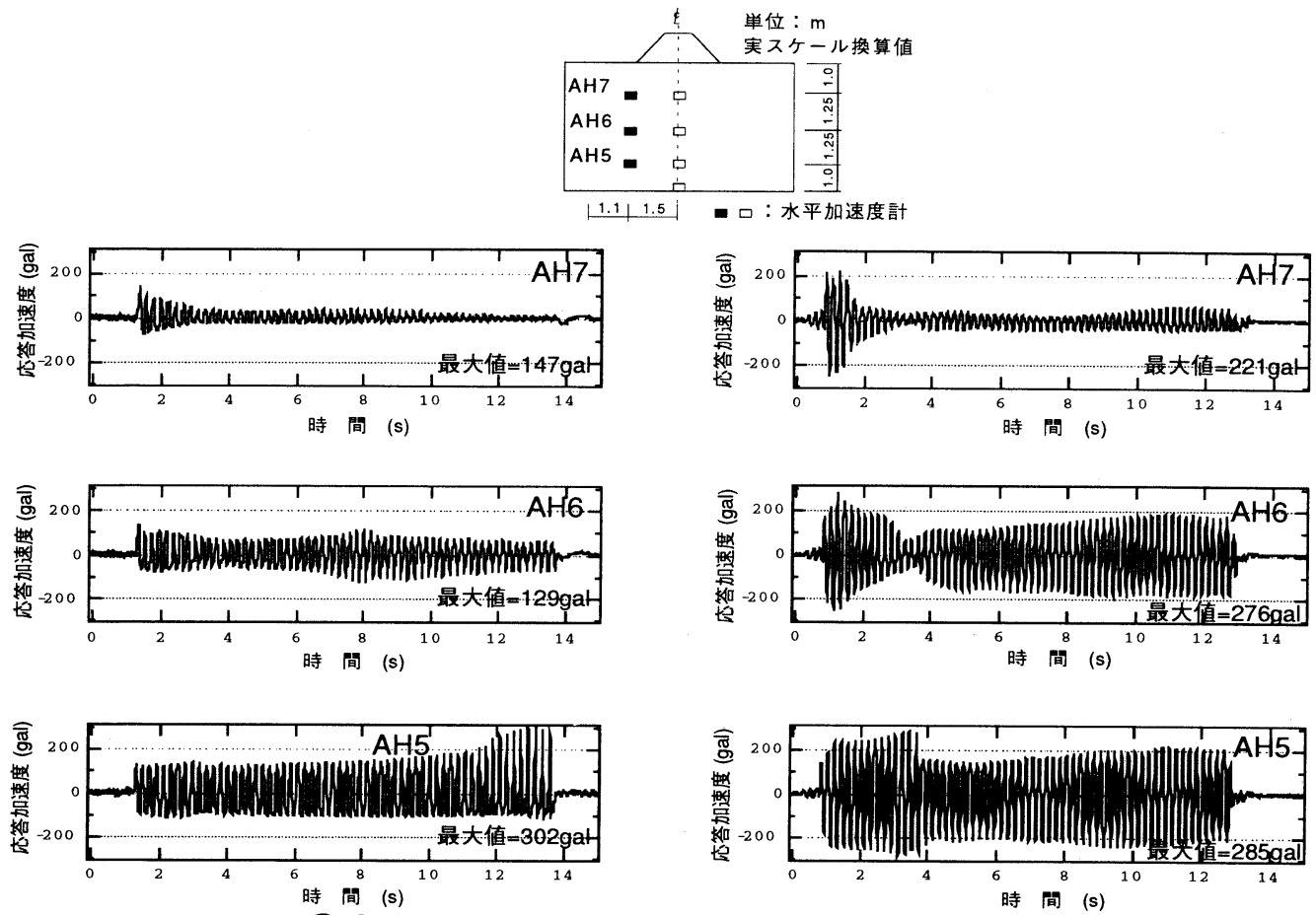

G-3
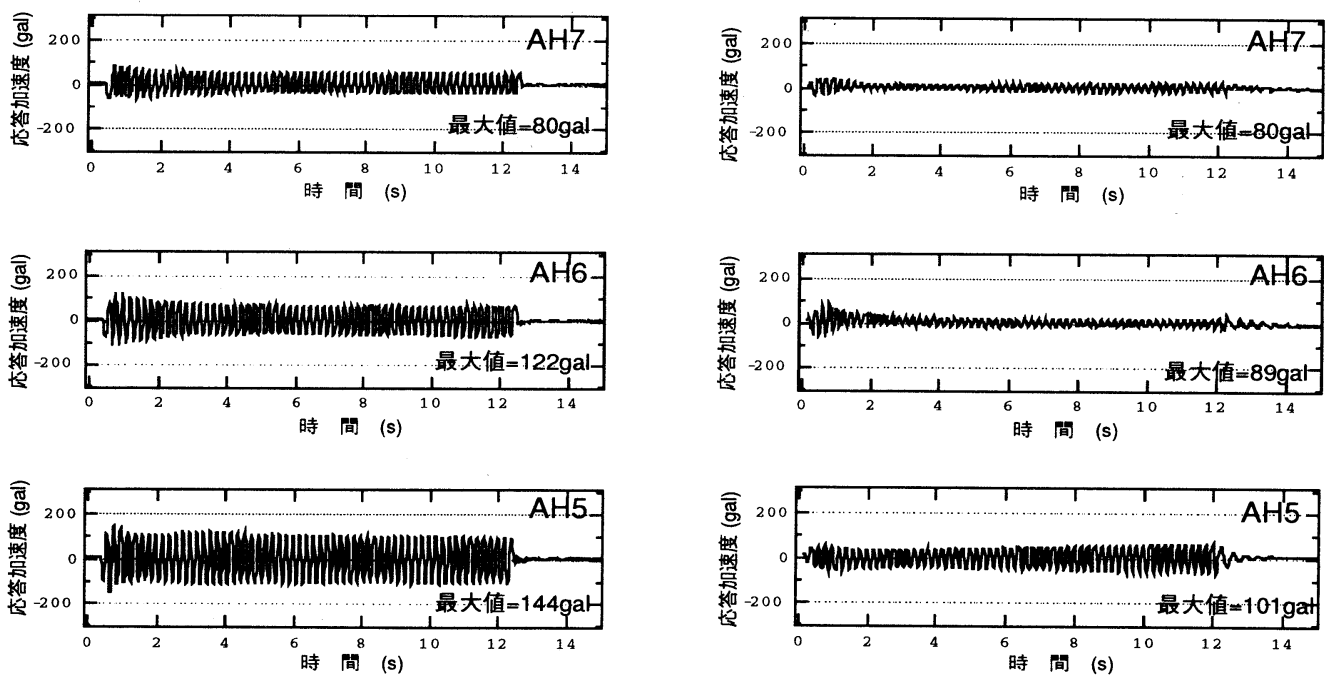

G-10

図一 6 応答加速度の時刻歴（盛土法尻位置）

図 - 7 (1), 図 - 7 (2) に重力場の 3つの実験と遠 心力場のC-20-1に打ける過㮃間隙水圧比の時刻歴 を示す. 過剩間隙水圧比を求める際の地盤内の初期 鉛直有効応力はポアソン比を 0.333 として弾性FEM 解析で算定している.なお， G-3では，加振より 20 秒でデー夕計測が終了している. また計器の故障か ら， G-10ではP6，C-20-2ではP4 の水圧計が欠測し た.
重力場での実験では各ケースの過㮃間隙水圧比の 相違は最大でも， $20 \%$ 以内に収まり, 設置位置毎に 良く似た挙動を示した．消散過程ではすべての水圧 計でG-3，G-5に比べG-10が遅くなった。

なお，G-3とG-5では，同じ相対密度の状態で，間 隙水として水を用いているため, 縮尺比の違いから G-5の方が $(5 / 3)^{0.75}=1.47$ 倍ほど透水係数が大きく なっている，消散過程をみるとG-3では，消散過程 

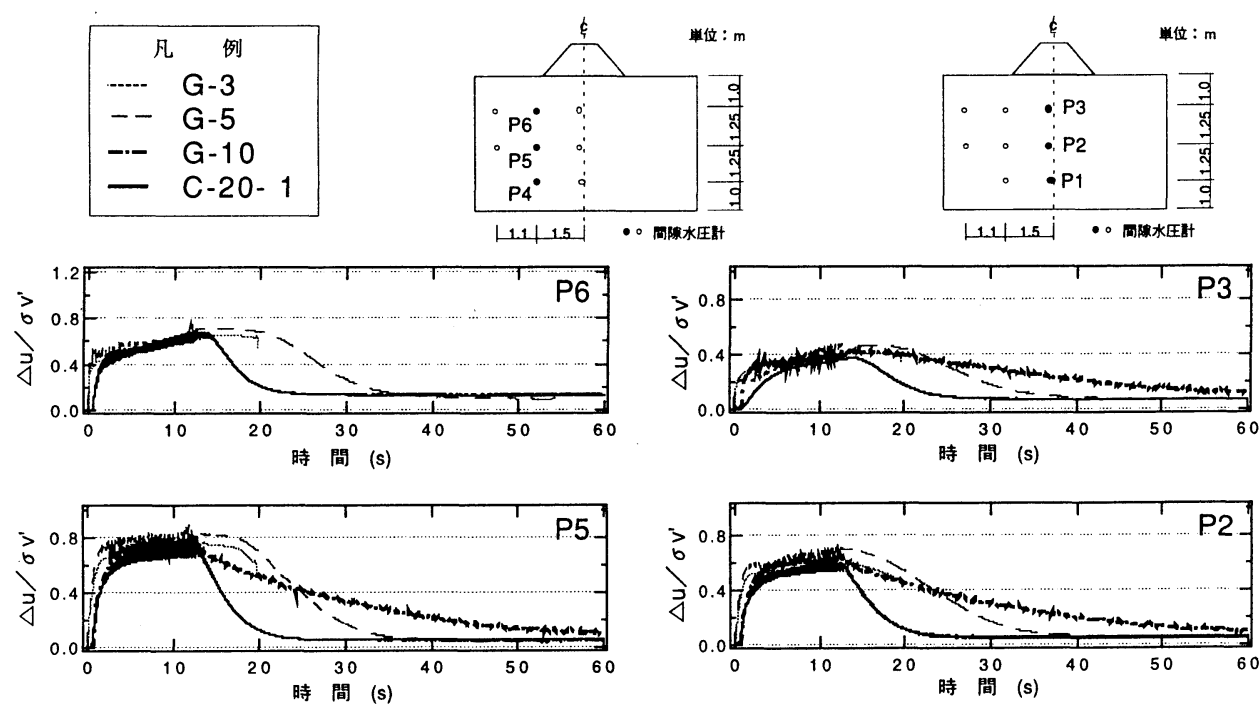

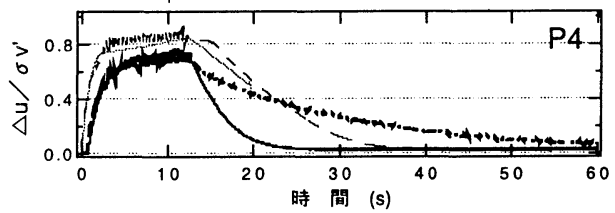

過剩間隙水圧比時刻歷（P $4 \sim P 6$ )

（1）盛土法尻直下

図一7 重力場と遠心場の過剩間隙水圧比の比較（G-3,G-5,G-10 および C-20-1）

(2) 盛土中央部直下

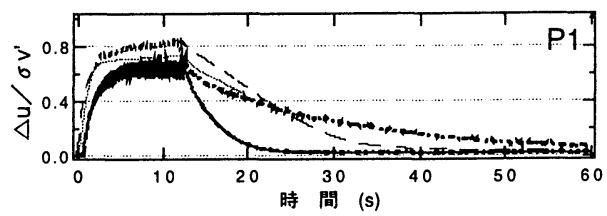

過剩間隙水圧比時刻歴（P 1 P 3 ）
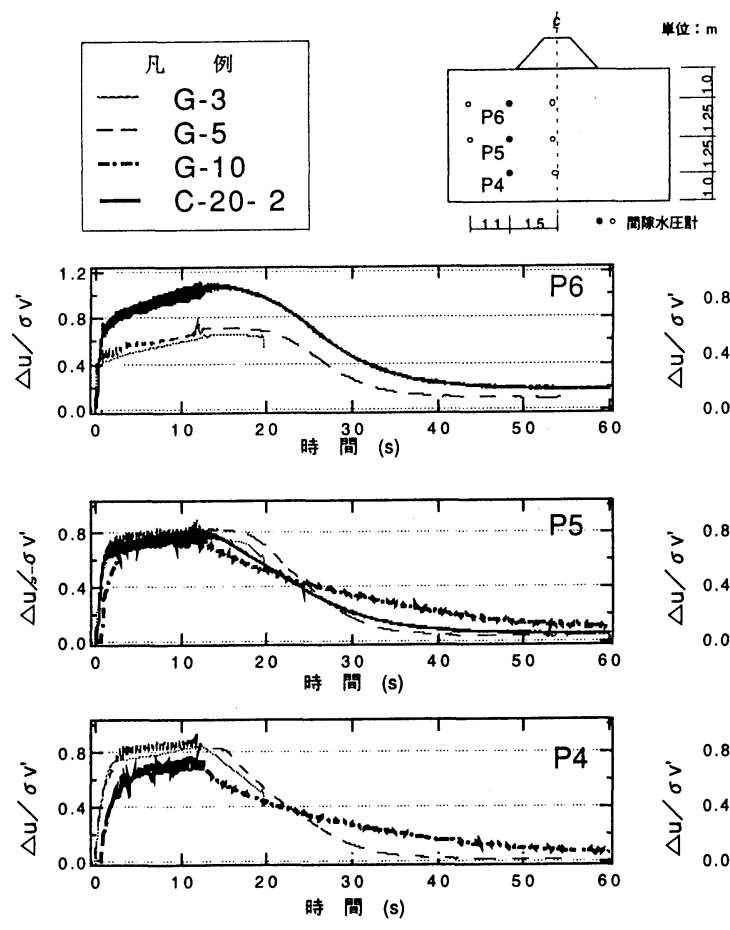

過剩間隙水圧比時刻歴 (P $4 \sim P 6$ )

（1）盛土法尻直下

図一8 重力場と遠心場の過剩間隙水圧比の比較（G-3,G-5,G-10 および C-20-2）
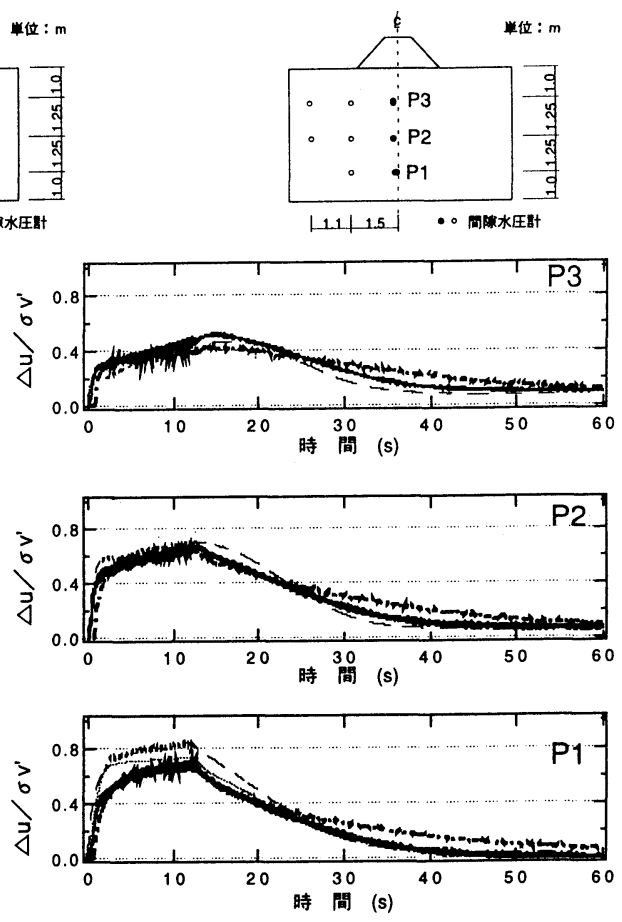

過剩間隙水圧比時刻歷（P 1 P 3 ）

(2) 盛土中央部直下 


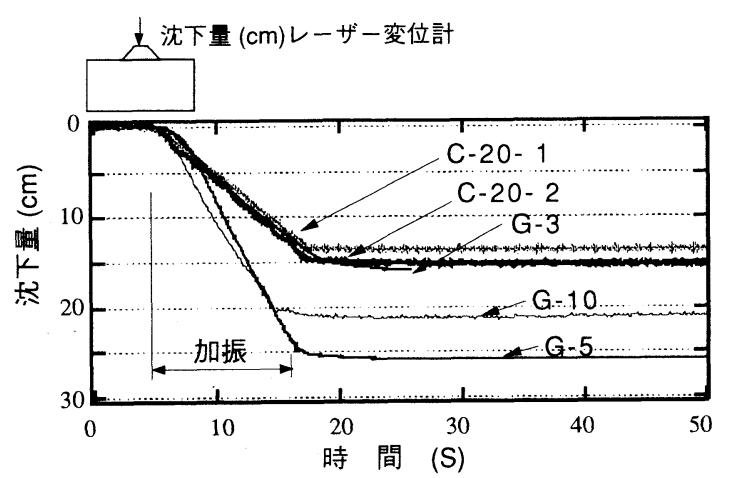

図一 9 盛土天端の沈下量の時刻歴

の初期までしか計測值はないが，この間ではG-5 と 比べ消散速度に差は見られず，今回の実験ではこの 原因について明らかにすることはできなかった.

C-20-1 は, 通常の遠心振動実験で用いられるよ うに長さの縮尺率 $1 / \mathrm{n}$ の逆数に等しい粘性係数の 間隙水を使用したものである. 重力場の各実験と遠 心力場のC-20-1を比較すると，加振による上昇時の 挙動は両者でほほ一致しているが, Koseki at el ${ }^{3)}$ 報告と同様に水圧の消散が重力場の実験に較べかな り速くなっていることがわかった。

これに対し, 図-8(1), 図-8(2) は重力場の各実 験と遠心力場の C - 20- 2 における各点の過剩間隙水 圧比の時刻歴を示したものである，C-20-2は先に述 べたように透水実験により実測された間隙水の粘性 と地盤の透水係数の関係を用いて間隙水の粘性を決 定しており，C-20-1に比べ50\%程度粘性の高いグリ セリン水溶液を使用している。このため，C-20-1に 比へ過剩間隙水圧の消散は遅くなっており, 過剩間 隙水圧の上昇から消散まで, 水圧比の最大値も含め て重力場の各ケースと良い一致が認められた。

これらの結果より, 過㮃間隙水圧の上昇はほほ非 排水状態で生じることから, 間隙水の粘性の相違に よる影響は小さいが，消散速度には粘性が大きく影 響を与えることがわかる。 また，地盤の透水係数に 関する相似則を一致させることで，遠心力場と重力 場における模型の過剩間隙水圧の消散挙動はある程 度一致することがわかった。

水圧計の挙動を見ると,すべての過剩間隙水圧は 加振後の数波で急激に上昇し, その後暫増してい る.また, 盛土直下では, 法尻位置の水圧計に比 べ, 初期鉛直荷重が大きいため, 過剩間隙水圧比は 小さくなっている，過剩間隙水圧比の消散過程を見 ると, 各ケースとも, 表面に近い位置の水圧計ほど 消散時間が遅くなっており，このことは風間らが 行った盛土の遠心模型実験の水圧計の傾向と同じで あった8).

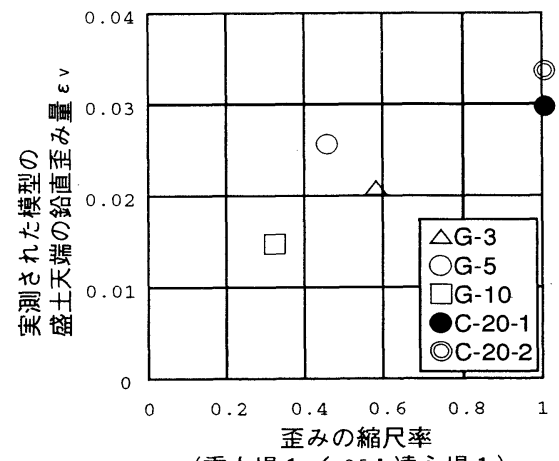

（重力場 $1 / \mathrm{n}^{0.5}$; 遠心場 1 )

図-10 歪みに関する縮尺率と模型の歪み量の関係

一方，図示は省略したが，周辺地盤位置における 過剩間隙水圧比（P7, P8）はすべての実験で1.0に 近い值となり, 周辺の地盤は完全液状化状態となっ た。

図－9に各実験の盛土天端の鉛直変位の時刻歴 を示す.すべての実験で, 盛土の沈下はほとんどが 加振中に生じ, 加振中は加振時間にほほ比例して沈 下が生じている。この結果は, 古賀らが行った盛土 の振動実験8) とほほ同様であった. 今回の実験では 地盤の透水係数が比較的大きかったために, 加振中 に排水が生じ, 沈下が発生したことが考えられる。 しかしながら, 盛土の直下では加振終了時に過剩間 隙水圧比は $0.5 \sim 0.8$ 程度であるにもかかわらず, そ れ以後の圧密沈下は微小であったことから推定する と, 盛土のような偏った荷重の構造物では, 液状化 に伴う過㮃間隙水圧の消散による圧密沈下よりも, 加振中の地盤の剛性の低下によって生ずるせん断変 形に起因する沈下の方が大きいと思われる.

また, 盛土天端の沈下量は入力加速度の大きい G-5 で約 $30 \mathrm{~cm}$ と若干大きくなった. 図一 10 に各 ケースの歪みに関する縮尺率と実測された模型の鉛 直歪み量との関係を示す. 井合の重力場の相似則で は, 歪みの縮尺率は実モデルの $1 / \mathrm{n}^{0.5}$ であり, 遠 心力場では 1 対 1 の関係がある. 同図を見ると入力 加速度の大きかったG-5を除くと, その他のケース で実測された模型の鉛直歪み量と歪みの縮尺率はほ ほ比例関係にあった。液状化時の地盤の変形量に は, 圧密沈下やせん断変形による沈下を含むため, 今回の実験だけでは, 沈下量に関する相似則の適合 を判断することはできないが, 図一10の実験結果

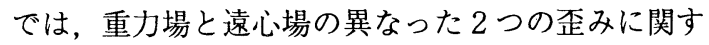
る相似則の適用結果はほほ一致した。

図－11に加振終了後に測定した地表面沈下量を 示す.なお，G-10の地表面沈下量に関しては，加 振終了後に地表面の沈下板が間隙水により浮き上が 


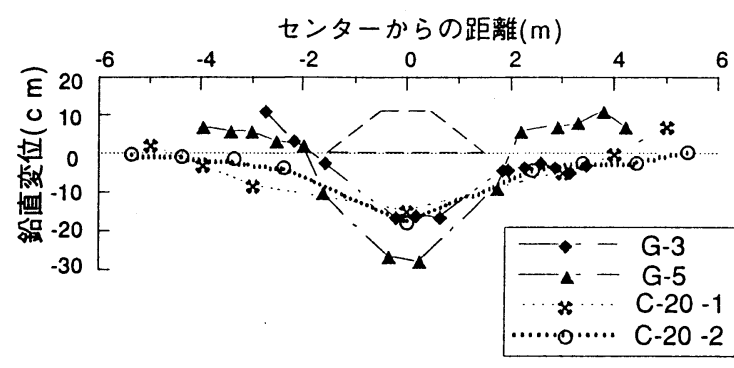

図ー1 1 各ケースの地表面沈下量

ったため，測定できなかった，盛土天端の沈下量の 差違は, 各ケースで $40 \%$ 程度に収まったが, 盛土の 周边部では, 重力場の G-3, G-5 と遠心力場のC20-1，C-20- 2 で異なる沈下の傾向となった. G-3 およびG-5では，非排水的な変形が主体となり，盛 土の下は沈下し, 盛土のない周辺部は若干隆起して いる，一方，C-20-1 およびC-20-2では，側方の地 表面を含む地盤面全体で沈下が生じた.

これらの理由として, 重力場の模型では遠心力場 に比べ，地盤内部の拘束圧力が小さいためダイレイ タンシーが大きくなったことことなどが考えられる が，この点について今回の実験だけで判断すること は難しく今後検討を要すると考える.

\section{4. 結論}

今回の一連の実験より以下の所見を得た.

（1）今回の重力場と遠心力場における実験を比較 すると, 地盤内の応答加速度に関しては, 模型の縮 尺率や土槽の形状によって微妙に影響を受けるた め，定量的な取り扱いは難しいことがわかった。た だし, 定性的には加速度の減衰や回復について加速 度計の設置位置毎に良く似た傾向を示した。

（2）過剩間隙水圧については, 重力場の実験と遠 心力場の実験で, 加振による水圧の上昇時の挙動は 定量的にも概ね一致した，消散過程に関しては，間 隙水の粘性と地盤の透水係数の実測值によって間隙 水の粘性を調整することにより, 重力場と遠心場の 実験結果は同様な挙動を示した.

（3）盛土天端の変形の経時的な変化は, すべての 実験で, 加振中に変形が進行し, 加振の終了ととも に変形の進行が終了した。 また, 沈下の歪み量につ いては, 入力加速度の大きかった G-5 を除くと, 実 測された模型の歪み量と歪みの縮尺率には, 比例的 な関係が認められ, 重力場と遠心場の 2 つの歪みに 関する相似則の適用結果はほほ一致した。

（4）地盤の透水係数を 1.5 倍程度変えた 2 つの遠
心力場の模型実験では, 加振時の挙動には大きな差 は認められなかったが, 加振後の水圧の消散時の挙 動が大きく異なった。このことから, 過剩間隙水圧 の消散を取り扱う問題では, 地盤の透水係数に影響 を与える間隙水の粘性あるいは粘性に影響を与える 間隙水の水温を管理して実験を行う必要があると考 えられる。

謝辞：本研究を行うにあたり，遠心模型実験に関し て協力を頂いた中央大学理工学部土木工学科土質基 礎工学研究室の皆様に感謝いたします。

\section{参考文献}

1) Ko,H.Y. : Modeling seismic problems in centrifuges, CENTIFUGE94, pp. 3-12, 1994.

2) Arulanandan,M.,Manzari,M.,Zeng,X.,Fagan,M.,Scott,R.F. \& Tan,T.S.: What the VELACS project has revealed., CENTIFUGE94, pp. 25-32,1994.

3) Koseki,J : Comparison of centrifuge and shaking table tests on liquefaction induced damage, Proc. of First International conf. on Earthquake Geotechinical Engineering, Vol.2, pp.729 -734,1995.

4）高田直俊, 日下部治：講座「遠心模型実験 3.原理」, 土と基礎，Vol35-12，pp. 89-93，1987.

5) 香川宗章 : 土構造物の模型振動実験における相似則, 土木学会論文報告集, 第275号, pp. $69-77,1978$ 年7月.

6) 国生, 岩楯：軟弱地盤の非線形振動特性についての模 型振動実験と解析, 土木学会論文報告集, 第2 85 号, pp.57 - 67, 1979.

7）井合進：1 G 場での地盤・構造物系の模型振動実験の 相似則について, 第19回地震工学研究発表会講演概要 集, pp. 341-344, 1987年.

8）古賀泰之, 古関潤一, 高橋晃浩：飽和砂地盤と盛土の 地震時挙動に関する動的遠心模型実験, 土と基礎, Vol. 412, pp. $17-22,1992$.

9) 風間基樹, 稲富隆昌, 飯塚栄寿, 永吉貴行 : 飽和砂地 盤上の盛土の地震時安定性に関する遠心力模型振動実 験, 土木学会論文報告集, 第547号/III-36, pp.107116,1996.9.

10）廣岡明彦, 酒見卓也, 川崎宏二, 山本陽一, 竹村次 朗：遠心模型振動実験手法の現状と課題「時間に関す る相似則と試料容器境界の影響に関する考察」, 東工 大土木工学研究報告No.53, 1996.3.

11）田中 満, 桶口雄一, 酒見卓也, 川崎宏二, 名倉克博 : 遠心載荷装置による液状化模型実験手法の基礎的研 究（その 1 遠心場に於ける間隙流体の透水特性）, 大成建設技術研究所法 第27号, pp.419-424, 1994年.

12) Sakemi,T.,Tanaka,M., Higuchi,Y.,Kawasaki,K. and Nagura, K. : Permeability of Pore Fluids in the Centrifugal Field, Proc. 10th. ARCSMFE, pp.481- 484, 1995. 


\title{
DIRECT COMPARISON OF GRAVITY MODEL AND \\ CENTRIFUGE MODEL FOR THE SEISMIC PROBLEM
}

\author{
Kentaro HAYASHI , Nariaki FUJII , Tomohiro MURAMATSU \\ and Kazuo HOUJYOU
}

\begin{abstract}
According to the both development of mechanics and electronics, the earthquake simulators for geotechnical model are used in centrifuge to take the place of that in the gravity field. But the similarity rule of a seismic behavior has been rarely investigated. This paper describes a series of shaking table tests carried out to compare the different scale model which is an embankment on a loose saturated sand. The sizes of reduced scale were the $1 / 3,1 / 5,1 / 10$ in the gravity field and the $1 / 20$ in the centrifuge. A good agreement was obtained in the dynamic behavior of excess pore pressures, acceleration response and surface settlement following the similarity rule respectively.
\end{abstract}

